\title{
Study of the Quality of Irrigation Water in South-East El-Kantara Canal, North Sinai, Egypt
}

\author{
Mohamed Gabr and Medhat El-Zahar
}

\begin{abstract}
The study examines the irrigation water quality for North Sinai Development Project (NSDP). The water resources investigated are agriculture wastewater mixed with Nile freshwater in a ratio of 1:1. This study focuses on the quality of irrigation water used in the reclamation and cultivation of 75,000 acres of the South-East EL-Kantra Canal lies in the NSDP. Six monitoring locations along the canal path were chosen for examination. Water samples were collected every month during the period from Dec. 2007 to Nov. 2014. The water parameters were set using the Egyptian irrigation water standards, based on the local Decree 92/2013 for the Executive Regulation of Law 48/1982, concerning the protection of the Nile River and its waterways from pollution, as well as the United States Environmental Agency, USEPA 2012 Guidelines for reclaimed water quality for irrigation. The results of the study clearly demonstrate restrictions to irrigate the uncooked vegetables and uncooked crops for human. The need for increasing the mixed Nile freshwater portion or pretreatment of the agriculture wastewater prior to mixing with the Nile freshwater to satisfy Egyptian irrigation water standards and USEPA 2012 as several water quality results, such as BOD, DO, and fecal coliform, are unacceptable. As a suggestion, we recommend using aerated lagoons, stabilization ponds or wetlands to treat polluted agriculture wastewater before adding to the Nile river water to satisfy Egyptian irrigation water criteria.
\end{abstract}

Index Terms-East South EL-Kantra Canal, agriculture wastewater, reuse, salinity, irrigation.

\section{INTRODUCTION}

Water quality and quantity are continuously degraded due to climatic changes and the increased demands for different water uses especially in agricultures practices. Moreover, cultivated land productivity is connected with soil and irrigation water quality [1]-[3]. Normally, investigation of irrigation water quality should focus on salt content, sodium concentration, the occurrence of nutrients and trace elements such as alkalinity, hardness of the water and acidity. Irrigation water quality is a major issue to insure safely produced plants. Water quality for agricultural purposes is measured according to the effect of water on the quality and yield of the crops as well as the effect on soil behavior [4]. The salinity, water infiltration, toxicity and miscellaneous are the commonly problems encountered soil fertility [5], [6].

Manuscript received February 26, 2018; revised May 27, 2018

Mohamed Gabr is with Civil Engineering Department, High Institute for Engineering and Technology, New Damietta, Egypt (e-mail: m_egabr@yahoo.com).

Medhat El-Zahar was with Port Said University, 42523, Port Said, Egypt $\mathrm{He}$ is now with the Department of Civil Engineering, Giza Engineering Institute, El-moneb, Giza, Egypt (e-mail: medhat.elzahar@gei.edu.eg, melzahar@yahoo.com).
Normally, better irrigation management provide the use of high salt concentration water without risking soil productivity.

Furthermore, the increase in salinity of fresh surface watercourses from the discharging of high salt concentrations coming from agriculture drains and waste effluents [7], [8]. Using better fresh water irrigation management, the irrigation efficiency increase and the amount of applied water for irrigation will be reduced. Drainage water is the part not consumed of the irrigation water applied to the crops, it can be reused according to its quality to meet the challenge fresh water shortage [9]. Total water resources in Egypt increased from 66.3 Billion $\mathrm{m}^{3}$ in 2006 to 78 Billion $\mathrm{m}^{3}$ in 2016 because of increasing agricultural drainage water recycling from 5.4 Billion $\mathrm{m}^{3}$ in 2005-2006 to 11.7 Billion $\mathrm{m}^{3}$ in 2015-2016. The agricultural wastewater reuse is frequently being perceived as an appreciated resource where, the demand for fresh water intensifies to compensate between supplies and demands. Reuse practices of agriculture wastewater in Egypt are, official reuse, intermediate reuse and unofficial reuse [9], [10]. This study examines the irrigation water quality for North Sinai Development Project (NSDP). This study focuses on the quality of irrigation water used in the reclamation and cultivation of 75,000 acres of the South-East EL-Kantra Canal. Six monitoring locations along the canal path were chosen for examination. Water samples were collected every month during the period from Dec. 2007 to Nov. 2014. The water quality parameters related to salinity such as total dissolved solids (TDS), sodium absorption ratio (SAR), hydrogen concentration (PH), organics such as dissolved oxygen (DO), biochemical oxygen demand (BOD), nutrients such as $\mathrm{NO}_{3}$, and pathogenicity such as (Fecal Coli) for the water samples were determined. The measured irrigation water parameters were analyzed and compared with the irrigation water standards for Egypt, the local Decree 92/2013 for the Executive Regulation of Law 48/1982, concerning the protection of the Nile River and its waterways from pollution, and the United States Environmental Agency (USEPA), 2012, guidelines for reclaimed water quality for irrigation.

\section{WATER QUALITY PARAMETERS}

\section{A. Salinity}

The salinity comprises total dissolved solids (TDS), electro conductivity (EC), sodium adsorption ratio (SAR), sodium $(\mathrm{Na})$, hydrogen concentration $(\mathrm{pH})$, and suspended solids (SS). It is one of the most important elements of water quality in judging its validity for irrigation. The high sodium adsorption ratio (SAR), demonstrates the potential damage in 
the soil, which is caused by the occurrence of high levels of sodium. Its value is given by the shown Equation [11]. The SAR value is an indicator to predict permissible sodium levels in irrigation water to maintain soil structural stability [12].

$$
S A R=\frac{\mathrm{Na}^{+}}{\sqrt{\frac{\mathrm{Ca_{x } ^ { 2 + }}+M g^{2+}}{2}}}
$$

Salinity standards for safe reuse of wastewater have been established by the FAO, then modified by, Westcot and Ayers 1985 [13], which put a restriction on uses divided into three degrees of severity: none, slight to moderate, and severe.

\section{B. Pathogenicity}

The most important indicators of the pollution of water resources are intestinal nematodes, E. coli, Fecal coliforms (FC), Total coliforms (TC). Fecal coliform bacteria presence in water is an indicator of pollution. It is characterized by its ability to grow in the laboratory at higher grades between $44 \sim 44.5^{\circ} \mathrm{C}$ and producing a proliferation of gas and acid [14]. Their presence in the water means the possibility of the presence of pathogens and is a serious threat to public health. Coliform group, total Coliform, they are found in soil, animal droppings and human feces. They can multiply in the laboratory at $35^{\circ} \mathrm{C}$ and $37^{\circ} \mathrm{C}$, and their production results in gas and acid during 24 48 hours. These bacteria have been selected for their presence in human fecal matter in abundance and for easy detection, where they remain in the water for longer periods of bacteria causing disease. WHO, 2006 [15] and USEPA 2012 [16] established guide lines for Fecal Coliform bacteria and total coliform concentration in wastewater reuse.

\section{Nutrients}

Nitrogen (NO3-N), Total Nitrogen (TN) and phosphorus $(\mathrm{P})$, are essential elements for plant growth and development and can increase the side effect on crop growth. Excessive nutrients in irrigation water are a source of groundwater contamination as well as eutrophication in coastal areas or lakes [17]. Ammonia is present in water as a result of the degradation of organic nitrogen and inorganic substances in water and soil by microorganisms. The increase in nitrogen in the water leads to an increase in aquatic plants and the growth of bacteria and algae [18].

\section{Biological Oxygen Demand}

It is the amount of oxygen consumed by microorganisms over a period of five days to oxidize the organic substances in water, and it is an indicator of the viability of the waterway for self-purification. The concentration of oxygen consumed gives an indication of the severe water pollution of bio-digestible organic matter [19].

\section{E. Chemical Oxygen Demand}

It is the amount of chemical oxygen consumed in the oxidation of all organic substances and is a proof of the total organic pollution of watercourses, BOD is part of the COD [19].

\section{F. Heavy Metals}

Heavy metals are naturally present in the ecosystem, with significant differences in concentration [19]. However, its recent increase in Egypt is due to industrial sources, liquid industrial waste and pollution from waste from fuel in particular [10].

\section{MATERIALS AND METHODS}

\section{A. Location of Investigation}

EL- Salam Canal Project (SCP) is one of the main parts of the national project for the development of North Sinai (NSDP). SCP water amount is established on the reuse of agricultural wastewater after mixing with Nile water by the ratio 1:1. The project also contributes to the creation of new urban communities for the purpose of alleviating the densely populated areas in the valley and linking the Sinai to the delta area. It has a natural extension of the valley. Estimated water amounts for the rehabilitation and cultivation of 620,000 are 4.45 billion cubic meters per year. The irrigation water mixed between fresh Nile water and agricultural drainage water by the ratio 1:1 expecting that Salinity don't exceed $1000 \mathrm{ppm}$ with the selection of suitable crop structures and distribution of water sources to feed EL-Salam canal as follows:

A) Water from Nile River, Damietta branch, 2.110 billion cubic meters annually.

B) Agricultural drainage water:

Water from Lower Sorrow Drain, 0.435 billion cubic meters annually,

Water from Bahr Hadous Drain, 1.905 billion cubic meters annually,

(Total required water resources 4.450 billion cubic meters per year).

TABLE I: WATER QUALITY MONITORING POINTS COORDINATES FOR EAST SOUTH KANTARA CANAL

\begin{tabular}{llcc}
\hline \hline \multirow{2}{*}{ Monitoring location } & \multicolumn{2}{c}{ Coordinates } \\
\cline { 2 - 4 } & & $\mathrm{E}$ & $\mathrm{N}$ \\
\hline & $\begin{array}{l}\text { At km 0.00 East South Kantara } \\
\text { Canal intake, } \\
\text { at km 14.7 on El-Sheikh Gabr } \\
\text { Canal }\end{array}$ & $32^{\circ} 28^{\prime} 10.48$ & $31^{\circ} 01^{\prime} 20.46^{\prime \prime}$ \\
\hline 2 & $\begin{array}{l}\text { At km 9.2 on East South } \\
\text { Kantara Canal }\end{array}$ & $32^{\circ} 30^{\prime} 46.02$ & $30^{\circ} 58^{\prime} 03.43^{\prime \prime}$ \\
\hline 3 & $\begin{array}{l}\text { At km 10.2 on East South } \\
\text { Kantara Canal }\end{array}$ & $32^{\circ} 28^{\prime} 28.49$ & $30^{\circ} 54^{\prime} 59.02^{\prime \prime}$ \\
\hline 4 & $\begin{array}{l}\text { At km 12.5 on East South } \\
\text { Kantara Canal }\end{array}$ & $32^{\circ} 29^{\prime} 35.17$ & $30^{\circ} 54^{\prime} 44.00^{\prime \prime}$ \\
\hline 5 & $\begin{array}{l}\text { At km 16.00 on East South } \\
\text { Kantara Canal }\end{array}$ & $32^{\circ} 29^{\prime} 13.37^{\prime \prime}$ & $30^{\circ} 53^{\prime} 00.97^{\prime \prime}$ \\
\hline 6 & $\begin{array}{l}\text { At km 18.3 on East South } \\
\text { Kantara Canal }\end{array}$ & $32^{\circ} 28^{\prime} 24.75^{\prime \prime}$ & $30^{\circ} 51^{\prime} 53.03^{\prime \prime}$ \\
\hline 7 & $\begin{array}{l}\text { At km 30.00 on East South } \\
\text { Kantara Canal }\end{array}$ & $\begin{array}{l}32^{\circ} 24^{\prime} 08.12 \\
"\end{array}$ & $30^{\circ} 47^{\prime} 04.85^{\prime \prime}$ \\
\hline \hline
\end{tabular}

Six monitoring locations along the canal path were chosen for examination. Water samples were collected every month during the period from Dec. 2007 to Nov. 2014. The total length of East South EL-Kantara Canal is $32 \mathrm{~km}$, Table I shows the coordinates of the monitoring locations.

This study focuses on the quality of irrigation water used in the reclamation and cultivation of 75,000 acres of the South-East EL-Kantara Canal. 


\section{B. Methodology and Water Sampling}

In order to examine the irrigation water quality of South East EL-Kantara on EL-Salam Canal, the following steps were conducted:

- Site visits to six monitoring points selected for the study were conducted.

- Water samples were collected monthly during five periods, (from Dec. 2007 to Nov. 2008), (from June 2009 to May 2010), (from Aug. 2010 to July 2011), (from April 2012 to Mars 2013), and (from Dec. 1013 to Nov. 2014).

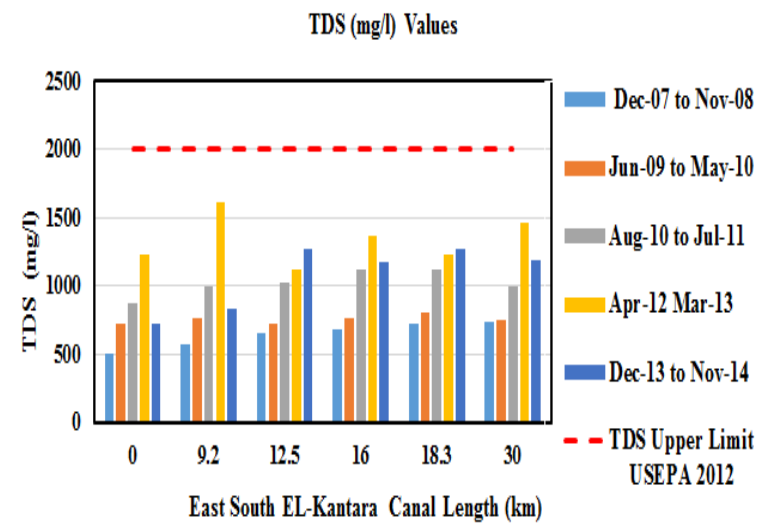

Fig. 1. East EL-Kantara Canal annual average TDS (mg/l).

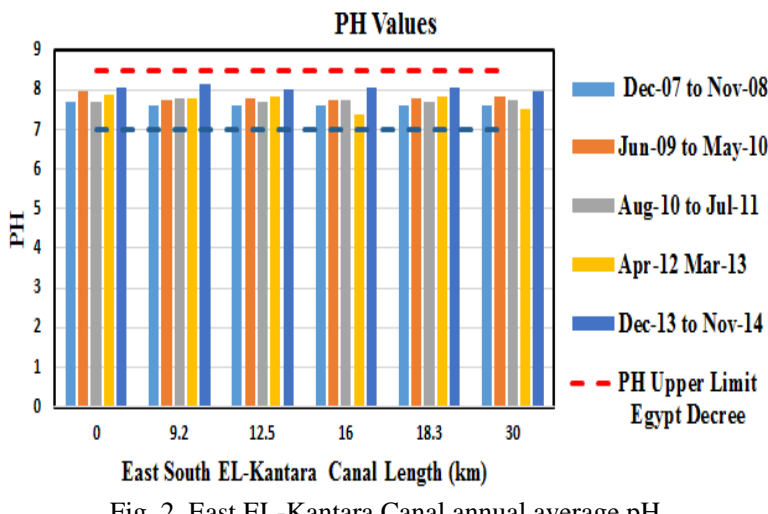

Fig. 2. East EL-Kantara Canal annual average $\mathrm{pH}$.

SAR Values

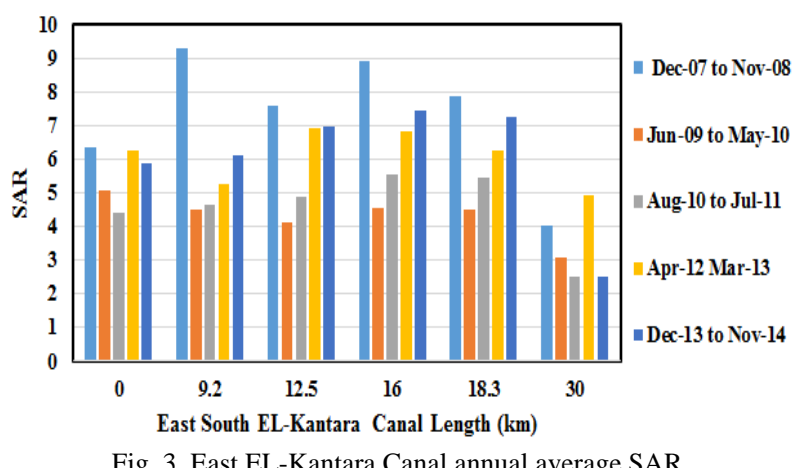

Assessment of agriculture wastewater reuse in irrigation purposes is necessary for the quality of plants and soil. In this study, water samples were drawn every month from the studied canal at locations $\mathrm{km}(0.00), \mathrm{km}(9.20), \mathrm{km}(12.50)$, $\mathrm{km}$ (16.00), $\mathrm{km}$ (18.30), and $\mathrm{km}(30.0)$. The water quality were examined in terms of, salinity (TDS, SAR, pH), organics (DO, BOD), nutrients $\left(\mathrm{NO}_{3}\right)$ and pathogenicity (Fecal Coli.). The results shown in this study were chosen for the period, June 2009 to May 2010, as a representative period for the measured parameters of water quality. The measured irrigation water quality parameters from each location were compared with the Egyptian standards Decree 92/2013, Executive Regulation of Law 48/1982 [20] that protects fresh water courses from pollution by the discharged effluents, and the USEPA 2012standards [16] for reclaimed water quality for irrigation.

The yearly arithmetic mean for the water parameter for the five periods with respect to upper and lower concentration levels for the chosen laws were presented in Fig. 1-7.

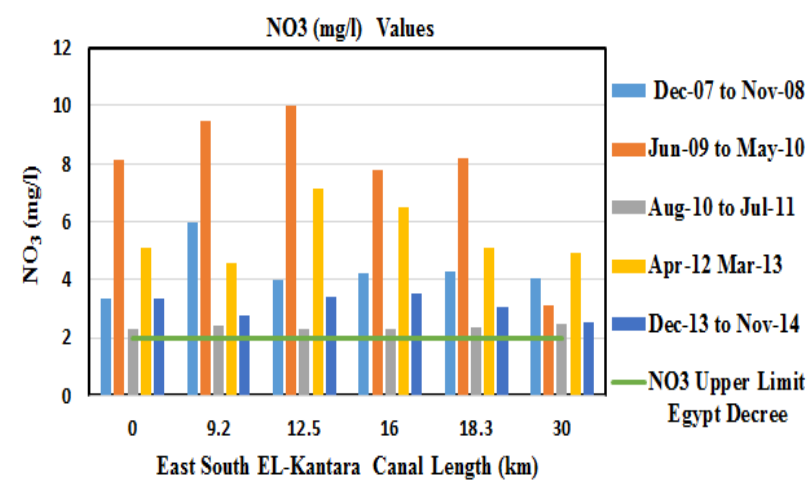

Fig. 4. East EL-Kantara Canal annual average $\mathrm{NO}_{3}(\mathrm{mg} / \mathrm{l})$.

$\mathrm{D} 0$ (mg/l) Values

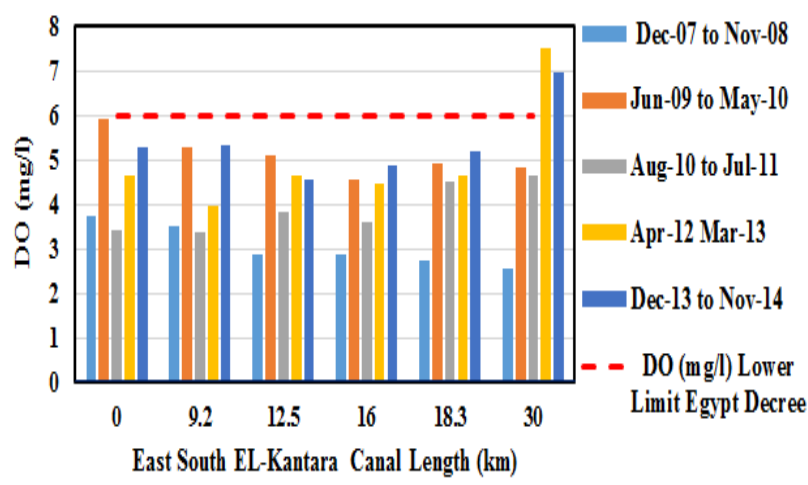

Fig. 5. East EL-Kantara Canal annual average DO (mg/l).

\section{RESUlTS AND DISCUSSION}

Fig. 1 shows the annual averages of the TDS concentrations along East South EL-Kantara Canal during the period from Dec. 2007 to Nov. 2014. The results show that the concentration mean value is $959.8 \mathrm{mg} / \mathrm{l}$, (the values ranged from 507 to $1309 \mathrm{mg} / \mathrm{l})$. These values are less than $2000 \mathrm{mg} / \mathrm{l}$ (FAO 1985 and USEPA 2012). However, the Decree 92/2013, Egyptian irrigation water standards have not specified a limit for the TDS [20]. According to the salinity degree restriction on irrigation, the TDS effect can be considered slight to moderate (USEPA 2012).

Fig. 2 shows the annual averages of $\mathrm{pH}$, the results show that all water samples mean value is 7.78 , (the values ranged from 7.38 to 8.13 ). The results mean that the water in the canal is alkaline. The measured $\mathrm{pH}$ values agreed with Egyptian Decree 92/2013, FAO 1985 and USEPA 2012 guidelines [16].

Fig. 3 shows the annual averages of the SAR values, the results show that the mean value is $5.6 \mathrm{mg} / \mathrm{l}$, (the values ranged from 2.51 to 9.31). Egyptian Decree 92/2013 for irrigation water standards have not specified the SAR limits. 
According to FAO 1985, USEPA 2012, infiltration is none (evaluated using EC and SAR).

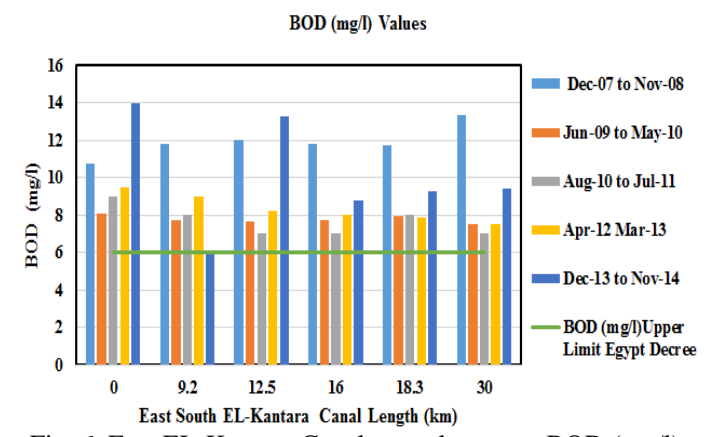

Fig. 6. East EL-Kantara Canal annual average BOD (mg/l).

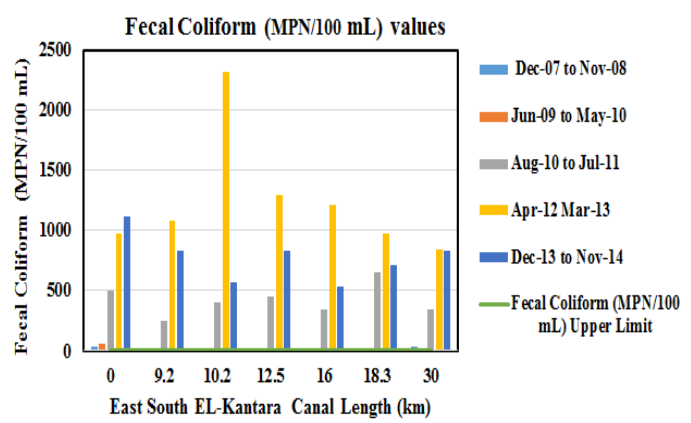

Fig. 7. East EL-Kantara Canal annual average Fecal Coliform (MPN/100 $\mathrm{mL})$.

Fig. 4 shows the annual averages of the $\mathrm{NO}_{3}$ values, the results show that the mean value is 4.85 , (the values ranged from 2.51 to $10 \mathrm{mg} / \mathrm{l}$ ), higher than the $2 \mathrm{mg} / \mathrm{l}$ specified by local Egyptian Decree 92/2013.

Fig. 5 shows the annual averages of the DO values. The results show that the mean value is $4.44 \mathrm{mg} / \mathrm{l}$, (the values ranged from 2.53 to $7.53 \mathrm{mg} / \mathrm{l}$ ). These values should be less than $6 \mathrm{mg} / \mathrm{l}$ specified by the local Decree 92/2013.

Fig. 6 shows the annual averages of the BOD values. The mean value is $9.05 \mathrm{mg} / \mathrm{l}$, (the values ranged from 5.01 to $19.97 \mathrm{mg} / \mathrm{l})$. These values are higher than the $6 \mathrm{mg} / \mathrm{l}$ specified by the local Decree 92/2013.

Fig. 7 shows the annual averages of the Fecal Coliform values. The results show that the mean value is 423 (MPN/100 ml), (the values ranged from 28 to 2325 (MPN/100 m). These values are higher than the 0.00 value specified by the local Decree 92/2013 for fresh water, and higher than the 200 median value specified by USEPA 2012.

According to the previous results, we should choose a proper method for treating wastewater before mixing with Nile River fresh water. The SAR value is a good indicator to predict permissible sodium levels in irrigation water to maintain soil structural stability [21], currently there are several desalination processes available for the reclamation of wastewater, such as reverse osmosis (RO), ion exchange (IX) and electro-dialysis [21]. Concerning the specific production of irrigation water from urban wastewater, IX and electro-dialysis are not found to be used for such purposes. While IX presents a poor selectivity for monovalent ions leading to lower desalination efficiencies and frequent regeneration of resins, the fouling in electro-dialysis is still an unsolved problem [22]. RO is the most frequently applied desalination technology [23], together with other pressure-driven membrane processes. The ability of these processes to remove certain components other than salinity makes them very attractive for reclamation for irrigation in general. The health risks of exposing agricultural workers, crop handlers and consumers to treated wastewater and associated chemical and microbial contaminants is one of the major barriers to water reclamation and reuse. Characteristics of influent wastewater, type of treatment process, applied hydraulic retention time (HRT), microorganisms present in the WWTP, $\mathrm{pH}$, temperature and the efficiency of suspended solids removal affect the removal efficiency of pathogenic and indicator microorganisms. The evaluation of technologies for pathogen removal is mostly based on fecal contamination indicators, such as total coliforms (TC), thermo-tolerant coliforms or Escherichia coli. Such indicators infer that pathogens may be present in the water. Chlorine, ultra-violet (UV), ozone, maturation ponds, constructed wetlands (CW), membrane filtration, deep bed filtration and electrochemical methods are being used for disinfection techniques and for elimination of pathogenic organisms [24]. CW are often reported as systems for treatment of irrigation runoffs, but less often for production of treated wastewater for irrigation.

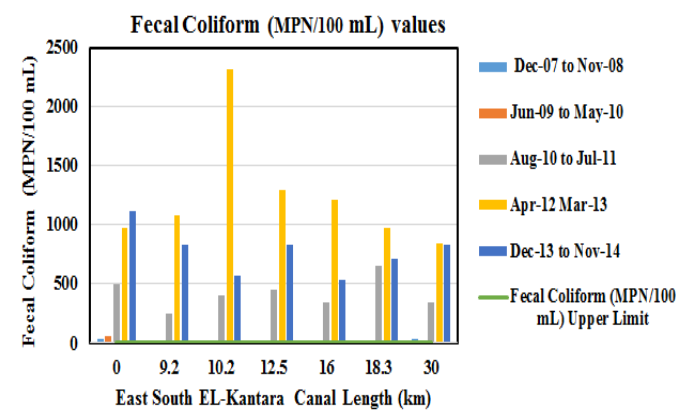

Fig. 7. East EL-Kantara Canal annual average Fecal Coliform (MPN/100 $\mathrm{mL})$.

\section{CONCLUSIONS}

The results of this study show the analysis of different parameters for irrigation water quality of East South EL-Kantra Canal during the duration, Dec.2007 - Nov.2014. The results confirmed the important need for more restrictions before using the mixed wastewater/water to irrigate agricultural products especially food crops. There is very serious need to, increase Nile River freshwater portion mixed with agriculture wastewater, or pre-treat the agriculture wastewater before mixing, to satisfy Egyptian irrigation water standards and USEPA, 2012. As a suggestion, we recommend using aerated lagoons, stabilization ponds or wetlands to treat polluted agriculture wastewater before mixing with the Nile River water to satisfy Egyptian irrigation water criteria.

\section{REFERENCES}

[1] C. Kirda, "Assessment of irrigation water quality," Options Me'dit A, vol. 31, pp. 368-377, 1997.

[2] S. C. Nishanthiny et al., "Irrigation water quality based on hydro chemical analysis," Jaffna, Sri Lanka. Am Eurasian J Agric Environ Sci., vol. 7, pp. 100-102, 2010.

[3] E. Selma, C. Semia, and T. Jamila, "Hydrochemical assessment of water quality for irrigation: A case study of the Medjerda River in Tunisia," Appl Water Sci., 2017, vol. 7, pp. 469-480. 
[4] D. W. Westcot and R. S. Ayers, "Water quality for agriculture," Food and Agriculture Organization (FAO) of the United Nations: Rome, Italy, 1985 .

[5] E. O. Longe and A. O. Ogundipe, "Assessment of wastewater discharge impact from a sewage treatment plant on lagoon water," Res J Appl Sci Eng Tech, vol. 2, pp. 274-282, 2010, Lagos, Nigeria.

[6] V. H. Smith et al., "Eutrophication: Impacts of excess nutrient inputs on freshwater, marine, and terrestrial ecosystems," Environ. Pollut., 1999, vol. 100, pp. 179-196.

[7] F. Brissaud, "Criteria for water recycling and reuse in the Mediterranean countries," Desalination, vol. 218, 2008, pp. 24-33.

[8] D. Chapman, "Water quality assessments - A guide to use of biota, sediments and water in environmental monitoring," UNESCO/WHO/UNEP, London SE1 8HN, UK, p. 651, 1996.

[9] L. S. Willardson, D. Boels, and L. K. Smedema, "Reuse of drainage water from irrigated areas," Irrigation and Drainage Systems, vol. 11, pp. 215-239, 1997, Kluwer Academic Publishers.

[10] A. Lubna and H. El Gammal, "Appraisal of blending water quality for agricultural reuse: Laboratory bench-top experiments," Life Science Journal, 2014, vol. 11, no. 12.

[11] Metcalf and Eddy 2003, Wastewater Engineering Treatment and Reuse McGraw Hill, New York, America.

[12] USEPA (United States Environmental Protection Agency), Guidelines for Water Reuse 600/R-12/618, Washington, DC, USA, 2012.

[13] D. W. Westcot and R. S. Ayers, Water Quality for Agriculture, Food and Agriculture Organization (FAO) of the United Nations: Rome, Italy, 1985

[14] G. Dichter. (2011). IDEXX Colilert-18 and Quanti-Tray Test Method for the Detection of Fecal Coliforms in Wastewater. [Online]. Available: https://www.idexx.com/resource-library/water/water-regarticle15C

[15] WHO (World Health Organization), "Guidelines for the safe use of wastewater, excreta and greywater," Wastewater Use in Agriculture, vol. 2, World Health Organization, Geneva, 2006.

[16] USEPA (United States Environmental Protection Agency), Guidelines for Water Reuse 600/R-12/618, Washington, DC, USA, 2012.

[17] X. T. Ju et al., "Nitrogen balance and groundwater nitrate contamination: Comparison among three intensive cropping systems on the North China Plain," Environ. Pollut., 2006, vol. 143, pp. $117-125$.

[18] D. W. Westcot and R. S. Ayers, Water Quality for Agriculture, 1985.

[19] T. Asano et al., Water Reuse: Issues, Technologies and Applications, McGraw-Hill: New York, NY, USA, 2007.

[20] Egypt Decree, "For the protection of the Nile River and its waterways from pollution," Decree of Minister of Water Resources and Irrigation no. 92 for year 2013 for the Executive Regulation of Law 48/1982, 2013.

[21] D. I. Chang et al., "Foulant identification and fouling control with iron oxide adsorption in electrodialysis for the desalination of secondary effluent," Desalination, vol. 236, no. 1-3, pp. 152-159, 2009.

[22] O. Elif and A. Sureyya, "Wastewater treatment by electrodialysis system and fouling problems," The Online Journal of Science and Technology, 2016, vol. 6, issue 1 .

[23] N. Kyle et al., "Electrochemical desalination for a sustainable water future," ChemElectroChem, Wiley-VCH Verlag GmbH \& Co. KGaA, Weinheim, 2014, vol. 1, pp. 850-857.

[24] N. Asmaa and A. Mohamed, "Technologies of domestic wastewater treatment and reuse: Options of application in developing countries," JSM Environ Sci Ecol., vol. 4, no. 3, p. 1033, 2016.

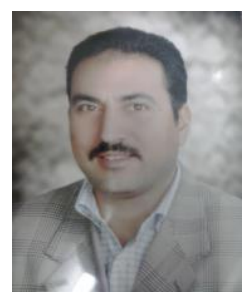

Mohamed Gabr is assistant professor in Civil Engineering Department, High Institute for Engineering and Technology, New Damietta, Ministry of Higher Education, Egypt. He got the Ph.D. in 2003 in civil engineering, Faculty of Engineering, Suez Canal University, Egypt. Dissertation: Generation and Transport of Sediments by Severe Flow Conditions. He was born in Port Said, Egypt, 1969. He has M.Sc. in environmental hydraulics (1997), Suez Canal University, Port Said, Egypt. Thesis: The Optimum Design for Protection and Lining of El-Salam Canal. He has B. Sc. in Civil Engineering Department (1991), Suez Canal University, Port Said, Egypt. Adjunct Assistant Professor, High Technological Institute, Tenth of Ramadan, Egypt. Civil Engineering department (2010-2012. Adjunct Assistant Professor, Civil Engineering, Faculty of Engineering, Suez Canal University, Egypt (2010-2011). Adjunct Assistant Professor, Department of Civil Engineering, Sabha High Technical Institution, Libya, (2004-2009). General Manager for Researches, Studies and Contracts Directorate, Reservoir and Great Barrage Sector, Ministry of Water Resources and Irrigation, preparing the detailed design studies for New Dirout Group of Regulators, preparing the contract for rehabilitation of Zefta Regulator, preparing the contract for the consulting services for New Dirout Group of Regulators Project. $2014-2015$, Senior engineer in the Studies and Design Directorate, North Sinai Sector for Irrigation and Infrastructures, Ministry of Water Resources and Irrigation, supervising the studies about irrigation drainage problems and water quality in North Sinai Project for reclamation and cultivation 400 thousand acres. 2013, General director for the upper Nile researches at South Sudan for the bilateral cooperation projects in field of water resources management between Egypt and South Sudan like, digging ground water wells, water discharge stations construction, land sides for navigation facilities and construction of pump station for drinking and irrigation purposes. 1994-1999, Civil Engineer in the North Sinai development organization, which implemented a big project in North Sinai in Egypt to reclaim and cultivate of 400 thousand acres.

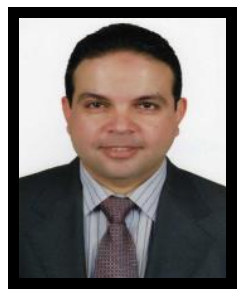

Medhat El-Zahar is associate professor specializing in environmental engineering with an emphasis on sanitary and environmental hydraulics with more than 15 years' experience in teaching at the undergraduate and graduate levels. Extensive experience in the planning, design and implementation of water supply and sanitation networks. He was born in Port Said, Egypt, 1969. He has a Ph. D. in sanitary and environmental hydraulics (2003), completed via a cooperative research program between Suez Canal University, Egypt, and the Kyushu Institute of Technology, Kitakyushu, Japan. Dissertation: Flotation and Dewatering of Waste Activated Sludge Using Carbon Dioxide. He has M.Sc. in Environmental Hydraulics (1997), Suez Canal University, Port Said, Egypt. Thesis: Improvement of Reliability of Water Distribution Networks. He has B. Sc. In Civil Engineering Department (1992), Suez Canal University, Port Said, Egypt.

He is now adjunct associate professor, the head of the Department, Giza Higher Institute of Engineering and Technology, Tamooh, Giza, Egypt, 2014-present. Adjunct Assistant Professor, Giza Higher Institute of Engineering and Technology, Tamooh, Giza, Egypt, 2012-2013. Adjunct Assistant Professor, Higher Institute of Engineering and Technology, New Damietta, Egypt, September, 2010-August, 2012, then 2014. Adjunct Assistant Professor, Higher Technological Institute, Tenth of Ramadan, Egypt, 09/2008-Present. Assistant Professor, Port Said University, Egypt, 05/2003-present (currently on leave). Visiting Researcher, Kyushu Institute of Technology, Kitakyushu, Japan, 08/1999-02/2002 (Research PhD topic based on developing innovative research on waste-water treatment). Lecturer, Suez Canal University, Port Said, Egypt, 1997-2003. Teaching Assistant, Suez Canal University, Port Said, Egypt, 1997-2003. Demonstrator, Suez Canal University, Port Said, Egypt, 1995-1997. Research Student, Suez Canal University, Port Said, Egypt, 1992-1995.

Assoc. Prof. El-Zahar has research interests in, developing new techniques for the treatment and re-use of sludge, a by-product of water treatment facilities, developing innovative techniques to treat domestic and industrial wastewater using greenhouse-gas emissions, and Improving and utilizing optimal designs for sedimentation and filtration units. 